\title{
Strengthening Brand Equity of Local Food to be a National Brand Class
}

\author{
J. Joko \\ Universitas Pendidikan Indonesia \\ Bandung, Indonesia \\ joko68@upi.edu \\ R. Hurriyati \\ School of Postgraduate Studies \\ Universitas Pendidikan Indonesia \\ Bandung, Indonesia
}

\begin{abstract}
Strategic Plan of Tourism Ministry period 20152019 sets the traditional culinary development as one element of tourists attraction. The policy encourages all regions in Indonesia in competing to explore the attractiveness, advantages, and selling value of their region unique traditional culinary either as a reception menu or as a gift by the tourists who come to visit. These developments have resulted in traditional trademarks transforming from the originally only one common name such as Moci, Peuyeum, Sale pisang, Bika Ambon, and so on, becoming branded and more distinguished from other producers (branding) in form of unique or different flavors, colors, and packaging (differentiation). These branding and differentiation efforts for traditional entrepreneurs are not planned on the basis of marketing principles to reinforce brand identity, brand image, and brand positioning through market research, in order to obtain an appropriate marketing mix strategy. Actually, the application of marketing principles is important for traditional culinary entrepreneurs to build brand equity, which in turn forms loyalty of their customers. Particularly in the Sukabumi region, one of the typical culinary is Moci, which is a round shaped rice-based flour and glutinous rice flour, generally contains green beans. Moci cake production is still produced traditionally so that it's free from preservatives, causing the snack can only last at most 3 days since made. Since the development of the accessibility in Sukabumi area where the delivery services and information technology enables to do online sales, it becomes a market opportunities for traditional culinary producers. To add, it can help the producer to seriously build their brand equity, in order to access the wider market share in national level, certainly by considering the freshness and expiration of the Moci product.
\end{abstract}

Keywords-Brand Equity; Tourism; Traditional Food; Brand Identity;

\section{INTRODUCTION}

Traditional food or cuisine is one valuable aspect in promoting tourism attractiveness of a destination. According to data from the Passenger Exit Survey (PES) in 2014, the largest contribution of tourists is to cultural tourism destinations (cultural and historical tourism, shopping and culinary, city and village) for $60 \%$, natural tourism (marine tourism, ecotour-ism, adventure) is $35 \%$, and artificial tourism (MICE tours and events, sports, integrated areas) is $5 \%$ of total contribution.

Almost each major tourism destination in Indone-sia has renowned unique cuisine that become local trademark such as bakpia in Yogyakarta, lumpia in Semarang, betutu chicken in Gilimanuk, shredded crab in Balikpapan, moci in Sukabumi, and so on. However, there are some local food brands such as Amanda Brownies and Bolen Mayasari from Bandung that after being branded and its equity seriously developed, were successes to be considered as a national brand, which easily to find in major airport in Indonesia.

According to Aaker Model [1], a particularly important concept for building brand equity is brand identity - the unique set of brand associations that represent what the brand stands for and promises to customers. Amanda and Mayasari are a successful brand that develop its brand equity through developing brand identity, brand awareness, and brand loyalty. They are sets of model that very possible being implemented to other traditional food or cuisine to become a national class brand.

According to Kotler \& Armstrong [2], a brand is a name, term, sign, symbol, or design, or a combination of these, intended to identify the goods or services of a maker or seller. 
the marketer's vision of what a brand should look like and what it should do for the consumer.

Meanwhile, according to the American Association, AMA, the key to create a brand is to "choose a name, logo, symbol, package design, or other attribute that identifies a product and distinguishes it from others" [2]. According to those definitions, the current position of most traditional food or cuisines are still on creating a brand.

The purpose of this research is to recognize the current brand level of traditional foods as mentioned above and make it as a national class cuisine like Amanda brownies and Mayasari bollen. The research is significantly to help local food producers, so that they can maximize the momentum of arriving more tourists to develop its brand equity. The problems concerning brand equity development of traditional food identified in the previous researches are the undefined brand element [3] and the difficulties to satisfy perceived quality expected by customers [4].

\section{A. Definition of brand equity}

The American Marketing Association defines a brand as' name, term, sign, emblem, or design, or a combination thereof, intended to identify goods or services of one seller or group of sellers and differentiate them from competitors. A mark is a product or service whose dimensions differentiates or constrains the brand in some way from other products or services designed to meet the same needs.

Brands also have a valuable role in the company:

- To make it easier when people search for a product

- To enable producers to protect their company's products with legal protection

Brand names may be protected through registered trade names, patents, copyright and proprietary de-sign. The brand informs the level of quality of a product so that consumers will find it easier to search/buy the product again.

Kotler interpret brand equity as added value endowed on product and services [5]. Meanwhile Tjiptono discloses that brand equity is a set of assets and liabilities associated with a brand, its name and its symbols that increase or de-crease the value of a given product or service to such company and or customer [6]. According to [7], brand equity also defines as increases for a product or destination the more it is differentiated, by the market, as superior to its closest competitors. It can be seen that their equity is a differentiator of a product, in this case, is a tourist destination, where the differen-tiator can be based from a consumer perspective. The consumer-based brand equity is an asset of four dimensions that are brand awareness, brand associations, perceived quality and brand loyalty [7]. According to Aaker in such competitive markets, reaching a sufficient position in consumers' mind that make him committed to the company is of great value and brand equity is one of the elements which can help the company with this brand equity. Brand equity divided into several elements: 1) brand awareness, 2) perceived quality, 3) brand association, and 4) brand loyalty [8]

Therefore, an important part of marketing is how to create the best experience for consumers for a product. In brand equity, there is also a brand promise (brand promise), which is

\section{B. Brand equity model}

Here are 4 models of models that have been accepted, namely:

- Brand asset appraiser.

The model is developed by advertising agency Young and Rubicam (Y \& R). There are five key components or pillars of brand equity:

- Differentiation measures the degree to which the brand is considered to be different from other brands

$\circ$ Energy measures the meaning of brand momentum

- Relevance measures the scope of brand attractiveness

- Self (esteem) measures how well brands are valued and respected

- Knowledge measures the level of consumer familiarity and intimacy

\section{Brand equity development}

Marketers build brand equity by creating the right brand knowledge structure for the right consumer. This process depends on all brand-related contacts whether marketers or not. Nevertheless, from the marketing management perspective, there are three main sets of brand equity drivers [9]:

- An initial choice for the brand element or identity that forms the brand (brand name, URL, logo, symbol, character, spokesperson, slogan, song, packaging, and billboards).

- Products and services as well as all marketing activities and accompanying marketing support programs.

- Any other association implicitly assigned to the mark by associating the mark with any other entity (person, place or item).

\section{Brand strengthening}

Brand equity is reinforced by marketing actions that consistently convey the meaning of a brand in terms of what products are branded, what core benefits are given, and what needs are met, and also how the brand makes the product superior, where the brand association strong, liked, and unique must be in the minds of consumers. An important part of brand reinforcement is providing consistent marketing sup-port in numbers and types. This consistency does not mean merely uniformity without change, many tactical changes may be necessary to maintain the strength and strategic direction of a brand [10].

\section{E. Brand Revitalization}


○ Brand to be considered

Changes in consumer tastes and preferences, the emergence of new competitors or new technologies, or all developments in the marketing environment can affect the brand's fortunes. Almost in all product categories, formerly known and admired brands such as Smith Corona, Zenith, and TWA are experiencing difficult times or even disappearing. However, some brands have reappeared impressively in the last year, with successful marketers breathing new franchises in their customers. The first thing to do in revitalizing a brand is to understand what sources of brand equity can be used as a starting point. Do negative associations begin to be associated with brands? Sometimes the actual marketing program becomes the source of the problem because the program fails to deliver the brand promise [11].

\section{RESULTS AND DISCUSSION}

\section{A. Efforts to strengthen brand equity to become a national} class brand

Results from the previous research, related to the development of brand equity product of Moci Cake from Sukabumi [4] and Timber from Kediri [3] tried to become a represented brand. The research showed that the dimension of brand equity consisting of brand awareness, brand association, brand perception, brand loyalty as a whole have a positive influence and brand loyalty in most of its consumers. The positive perception has a significant effect on the interest to for most consumers to buy and choose again the brand in the future.

Brand awareness; re-buying interest arises be-cause consumers are able to remember the Moci and Timbel brand. Brand association; re-buying interest arises because of strong consumer's awareness that Moci cakes are typical of Sukabumi and Timbel of Kediri. Perception of quality; re-buying interest ad-heres because consumers are satisfied with service of Kaswari Lampion as producer of moci and Depot Rasa Suka as producer of Timbel, in particular for easiness of transaction. Brand loyalty; rebuying interest arises also because consumers love all things related to the Moci cake product of Kaswari Lampion brand, as well as the timbel from Depot Rasa.

Those two brands showed the systematic, integrated and sustainable efforts must be made to strengthen the brand equity, similar with Amanda and Mayasari did. Before it can be strengthened and developed to elevate them to national level brands. The development model can be studied below [12]

- Brand loyalty
○ Reduced marketing costs
○ Attracting new customers
○ Time to respond to competitive threats

- Brand awareness

- Anchor to which other association can be attached

- Familiarity

- Signal of substance
- $\quad$ Perceived quality

- Reason to buy

- Differentiate / position

- Price

- Channel member interest

$\circ$ Extentions

- Brand associations

- Help process and retrieve information

- Differentiate / position

- Reason to buy

- Barrier to competitors

○ Extensions

- Other proprietary brand assets

- Competitive advantage

- Brand equity

- Provides value to customer by enchacing customer's: a) intrepretation / processing of information, b) confidence in the purchase decision, and c) use satisfaction.

o Provides value to firm by enchaching: a) efficiency of marketing program, b) brand loyalty, c) price / margins, d) brand extensions, e) trade leverage, and d) competitive advantage.

\section{B. The Efforts to strengthen brand equity}

Some efforts that can be done to strengthen the brand equity of Sukabumi Moci cake products in-clude:

- Certification of culinary products

Modern markets such as Superindo, Giant, Carrefour, Mini Market, Supermarkets, and food market usually requested in the packaging of their products there must be a certificate of Household Food In-dustry (PIRT) given by District Health Office, similarly Halal certification from Majelis Ulama Indonesia (MUI). Those are important to strengthen the brand equity of Sukabumi Moci cake product because it will increase the brand trust of potential consumers who do not buy directly from its factory in Sukabumi City, for the quality, health, and safety of such culinary products.

- Develops more attractive packaging

Packaging has two important roles in the development of culinary products. First serves as a protector of food products to be durable according to expiry time that is not easily damaged by exposure to sunlight, odor, moisture, dust, and many sources of external impurities (external) in order to strengthen 
using social media, we need the right strategy. It must be ensured that the social media has many users, the tools provided by various social media like Facebook, Twitter, LinkedIn, Foursquare, Myspace, and Word Press to have a content management service that enables users to promote.

\section{- Do a co-branding} businesses that already exist. One of the efforts that can be taken to face the increasingly sharp trade competition is through packaging [13]. The attractiveness of a product cannot be separated from its packaging. Packaging is an early appeal because directly faced with consumers, therefore packaging should be able to influence consumers to obtain a positive response, in this case, buy the product because the ultimate goal of packaging is to create sales.

\section{- Development of distribution networks}

The examples of typical culinary products that managed to become a national class Brand with the development of distribution network is the product of Kartika Sari, Mayasari Bolen cakes, and Amanda brownies cakes are all originally typical local cakes from the city of Bandung. All three brands have become a national brand because the consumers all over Indonesia can easily afford it. This is possible because the distribution network of these three products has been well established. For example, in almost every major airport such as Sukarno-Hatta, Semarang, Surabaya, Denpasar, Balikpapan, Medan, and Makassar which are hubs to other more inland airports, outlets of one or three of these products can be found. The third outlets of the product are also easily found in many rest areas along highways and major tourist attractions visited by many visitors from all over the archipelago and abroad. With the many national-level project plans in Sukabumi and its surroundings, as well as the entry of Sukabumi City as part of the Java Island toll road, it is an ex-cellent momentum to develop a culinary distribution network typical of Sukabumi City, with Moci cake as its main prima donna.

\section{Brand equity development effort}

- Social media

Currently, social media is an important part of marketing a brand. Through social media, it is not only the products that become the focus but also the consumers. Through the social media, a brand can interact with consumers and potential customers directly. By creating a brand experience in accordance with the wishes of consumers and involve them become part of the brand narrative culinary products. This can help to increase consumer confidence in brands that are more difficult to build through traditional marketing and advertising ways. Social media can also be used to see the reaction and response of consumers to the development of products made. This can help provide insight into adjusting future promotional strategies. In
One of the efforts to increase brand awareness is cobranding with big brands, to work on event or marketing campaign together. At least big brands have regular campaign budgets and schedules at the national level that can encourage the adoption of a brand that has not been widely known. In particular, if the big brand has a quota of advertising in a number of media. However, many things need to anticipate first, one of them, brands that work together must have the same consumer profile or adjacent to the culinary segment.

\section{- Influencer marketing}

Influencer marketing is a marketing strategy to promote a product through influencers in social media like Instagram, Youtube, Twitter, blogs, etc. Influencers here are people who have a lot of followers in social media and have a strong influence on their followers like blogger, youtuber, selebgram, and so forth. The influencers are usually well-liked and trusted by their followers so that what they say and do can influence followers to try and buy a product. Bloglovin, a platform for reading all your favorite blogs in one place, surveyed with 100 marketing experts on influencer marketing. Based on the survey results, many brands are using current influencer marketing because this method is very helpful to increase brand awareness, reach the target audience, and also introduce their products through content created by influencers. A brand ambassador such as artists or national figures is another form of influencer marketing that is now widely used by producers.

\section{CONCLUSIONS}

Brand equity is the added value given to products and services that can be observed in the way consumers think, feel, and act in relation to the brand and also the price, market share, and profitability that the brand brings to the company. The customer-based brand equity is the differential influence that the brand's knowledge of the consumer's response to the brand's marketing. A brand has positive customer-based brand equity when the consumer reacts more positively to the product and the way it is marketed when the brand is identified.

Positive things need to be studied more in-depth in order to be able to audit brand (brand audit), so it can be ascertained branding and differentiation efforts for traditional entrepreneurs can be more planned based on the principles of marketing to strengthen the identity (brand identity), brand image and brand positioning through market research, in order to obtain an appropriate marketing mix strategy. 
the \passengers of international flight at Garuda Indonesia Airlines.

The application of marketing principles is important for traditional culinary entrepreneurs to build brand equity which in turn forms customer loyalty (brand loyalty) as the most valuable part of brand equity.

\section{REFERENCES}

[1] Aaker, D.A. and K.L. Keller. 1993. Interpreting cross-cultural replications of brand extension research. International Journal of Research in Marketing 10: 55-59.

[2] Mirzai, A., Fard, Y. S., \& Slambolchi, A. 2016. The branding: A study of brand image, brand associations and reputation. Advanced Social Humanities and Management 3(1): 52-54.

[3] Raharjo, R., et al. 2013. Pengembangan merek dan pengkajian strategi pemasaran di depot rasa suka Kediri. Calyptra, 02 (01).

[4] Dewi, M. P. 2013. Pengaruh ekuitas merek terhadap minat beli ulang pada produk kue mochi merek kaswari lampion di Kota Sukabumi. IPB.

[5] Kotler, P., \& Keller, K. L. 2009. Marketing management. Or-ganization 22.

[6] Budiarti, A. 2013. Brand equity and customer satisfaction as the mediation of $\backslash$ advertisement influence and the service quality to loyalty IOSR Journal of Business and Management (IOSR-JBM) 9(2): 01-15.

[7] Maulani, Terra S., \& Prasetyo, M. H. 2016. Analisis ekuitas merek wisata kuliner berdasarkan perspektif wisatawan dan pengaruhnya dalam meningkatkan nilai pelanggan (Studi kasus pada produk sentra ikm makanan tradisional di kota bandung). Banking \& Management Review, 865-878.

[8] Miremadi, A., Rezagharehdaghi, M., \& Milani, M. 2014. A comprehensive study on customer based brand equity in iranian private banking. Indian Journal of Fundamental and Applied Life Sciences 4(S3): 2231-6345.

[9] Rossolatos, G. 2013. Brand equity planning with structuralist rhetorical semiotics: A conceptual framework. The Qualita-tive Report 18.

[10] Schoeman, W. 2012. Antecedents and consequences of brand equity and brand value of business to business environ-ments within the Gauteng province mini-dissertation sub-mitted for the degree Masters in of the North-West Univer-sity, (November).

[11] Heding, T., Knudtzen, C. F., \& Bjerre, M. 2009. Brand Man-agement Research, theory and practice.

[12] Moisescu, O. L. 2005. The concept of brand equity - A Com-parative Approach. MPRA Paper No. 32013.

[13] Uchyani, R., \& Irianto, H. 2016. Pengembangan pasar produk olahan kacang melalui perbaikan kemasan. Asian Journal of Innovation and Entrepreneurship, 01(01). 